\title{
Partisipasi Masyarakat Kota Pematangsiantar Membangun Kota Hijau
}

\author{
Marulam MT Simarmata \\ Staf Pengajar Program Studi Kehutanan Fakultas Pertanian USI \\ e-mail : marulamsimarmata@yahoo.com
}

\begin{abstract}
Abstrak
Pembangunan kota sering lebih banyak dicerminkan oleh adanya perkembangan fisik kota berupa sarana dan prasarana. Pertumbuhan dan perkembangan Kota Pematangsiantar yang berlangsung hingga saat ini berimplikasi pada berkurangnya ruang terbuka, sebagai akibat dari pertumbuhan penduduk, karena meningkatnya lahan terbangun untuk pemenuhan lahan bagi fasilitas dan fungsi-fungsi perkotaan lainnya Penelitian bertujuan untuk mengetahui partisipasi masyarakat membangun kota hijau, serta mendapatkan data terhadap peluang yang dapat dilaksanakan dari delapan komponen green city di wilayah studi.

Penelitian menggunakan teknik kombinasi antara observasi dan kuesioner. Responden 100 orang, ditetapkan secara acak dengan unit rumah tangga. Data yang terkumpul ditabulas.

Berdasarkan hasil analisis data dan pengamatan menunjukkan bahwa sikap responden terhadap kesediaan mendukung program kota hijau menunjukkan sikap yang positif dan responden menunjukkan sikap yang positif dan netral terhadap kesediaannya melaksanakan program kota hijau.
\end{abstract}

Kata Kunci : Kota Hijau, Sikap, Dukungan

\section{PENDAHULUAN}

\section{A. Latar Belakang}

Kota sebagai tempat berkumpulnya penduduk cepat mengalami perkembangan karena mempunyai daya tarik tersendiri bagi penduduk perdesaan. Perkembangan kota ini akan lebih cepat bila didukung oleh potensi alamiah dari kota itu, kota yang berada di jalur perdagangan dan jasa didukung potensi daerah hinterland yang baik akan berkembang dengan cepat. Kecepatan perkembangan akan memerlukan penyediaan fasilitas yang cukup banyak, dan ini tentu tidak bisa dengan cepat dipenuhi. Lama kelamaan di kota tersebut akan timbul berbagai masalah karena adanya ketidakseimbangan antara kebutuhan penduduk dengan daya dukung lingkungan. Untuk mengatasi hal tersebut dalam pembangunan perkotaan perlu memperhatikan daya dukung lingkungan sehingga pembangunan yang dilakukan dapat berkesinambungan.

$$
\text { Pembangunan kota sering lebih }
$$
banyak dicerminkan oleh adanya perkembangan fisik kota berupa sarana dan prasarana. Lahan-lahan pertanian yang subur, ruang terbuka hijau banyak dialihfungsikan menjadi pertokoan, permukiman, tempat rekreasi, industry, dan lainlain, sehingga lingkungan terganggu. Oleh karena itu terganggunya kestabilan ekosistem perkotaan, maka alam menunjukkan reaksinya yang negative berupa : meningkatnya suhu udara di per- 
kotaan, banjir/genangan, meningkatnya kebisingan, penurunan permukaan air tanah, pencemaran air berupa air minum yang berbau, air minum yang mengandung logam berat, pencemaran udara dan sebagainya.

Lingkungan dapat ditata menjadi berfungsi ekologis dan sosial yakni dapat menyediakan ruang untuk aktivitas keluarga di luar ruangan yang nyaman dan indah. Fungsi lain RTH adalah untuk menambah daya dukung kota dan konservasi air dan udara. Bentuk timbale balik penataan RTH tidak hanya terbatas berupa kualitas kenyamanan suasana lingkungan lingkungan, tetapi lebih jauh akan meningkatkan produktivitas serta melahirkan keberlangsungan hidup dan penghidupan yang lebih baik karena adanya keseimbangan ekologis.

Green City secara harfiah dapat diartikan sebagai kota hijau, yang diharapkan akan tumbuh kembang sebagai kampanye pemanfaatan florikultura untuk cipta pasar dalam negeri secara sistemik. Green City mempunyai 8 komponen yaitu green planning and design, green open space, green waste, green transportation, green water, green energy, green building dan green community.

Kota Pematangsiantar merupakan kota terbesar kedua setelah kota Medan di Propinsi Sumatera Utara. Keberadaan kota
Pematangsiantar sebagai wilayah strategis dan pusat distribusi regional dengan daerah sekitarnya (hinterland) serta pusat pembangunan wilayah (dulu Wilayah II) di Propinsi Sumatera Utara (Simalungun, Karo, Dairi, Toba Samosir, dan Tapanuli Utara).

Pertumbuhan dan perkembangan Kota Pematangsiantar yang berlangsung hingga saat ini berimplikasi pada berkurangnya ruang terbuka (non terbangun), sebagai akibat dari pertumbuhan penduduk, karena meningkatnya lahan terbangun untuk pemenuhan lahan bagi fasilitas dan fungsi-fungsi perkotaan lainnya.

Pembangunan di Kota Pematangsiantar merupakan rangkaian upaya pembangunan yang berkesinambungan yang meliputi seluruh aspek kehidupan. Kawasan Kota Pematangsiantar merupakan tempat yang sangat menarik bagi masyarakat untuk mengembangkan kehidupan sosial ekonomi. Kehidupan sosial ekonomi berpengaruh terhadap pertumbuhan penduduk baik secara alamiah maupun migrasi sehingga menyebabkan tidak terkendalinya perkembangan pemukiman dan lingkungan perumahan.

Faktor yang sangat penting dalam permasalahan lingkungan adalah besarnya populasi manusia. Pertumbuhan penduduk merupakan faktor utama yang mempengaruhi perkembangan pemuki- 
man dan kebutuhan prasarana dan sarana. Selama periode 1988-2008 kota Pematangsiantar mengalami pertumbuhan penduduk secara kontiniu dari 207.896 jiwa menjadi 249.985 jiwa, dimana selama periode tersebut mengalami laju pertumbuhan rata-rata penduduk sebesar $0,93 \%$ pertahun.

Ruang terbuka hijau semakin terdesak keberadaannya dan berubah menjadi bangunan untuk mencukupi kebutuhan fasilitas penduduk kota. Penyebaran jumlah penduduk yang tidak merata dalam suatu wilayah, akan memberikan pengaruh yang negatif terhadap daya dukung lingkungan. Rencana tata ruang yang merupakan aplikasi pera-turan mengenai ruang terbuka hijau, belum bisa diwujudkan dengan baik untuk mengakomodasi aspek-aspek yang membutuhkan ruang terbuka hijau.

Program Pemerintah Kota Pematangsiantar sejak tahun 2011 telah mencanangkan menjadikan Pematangsiantar green city, hal ini di dukung dengan alokasi anggaran belanja daerah tahun 2012 telah dialokasikan dana sebesar 2,8 miliar rupiah dengan asumsi setiap kecamatan mendapat anggaran sebesar 350 juta rupiah, dengan kegiatan penanaman pohon pelindung dan produktif. Kepala kelurahan sebagai pejabat pelaksana teknis kegiatan untuk merangkul komunitas masyarakat di daerahnya membagi-bagi bibit pohon. Terdapat bibit pohon pelindung yang ditanam di turus jalan dan bibit pohon produktif ditanam di pekarangan rumah warga.

Sekaitan dengan program menciptakan kota Pematangsiantar menjadi green city perlu dikaji sejauhmana persepsi dan sikap masyarakat khususnya inti kota (central business Districk) untuk mendukung program dimaksud, mengingat keterbatasan lahan yang telah terbangun pada wilayah dimaksud.

\section{B. Tujuan Penelitian}

Penelitian ini dilakukan bertujuan untuk mengetahui partisipasi masyarakat membangun kota hijau serta mendapatkan data terhadap peluang yang dapat dilaksanakan dari delapan komponen green city di wilayah studi

\section{BAHAN DAN METODA}

\section{A. Tempat dan Waktu}

Penelitian dilaksanakan selama 3 bulan yang dimulai sejak bulan Agustus 2013 s/d. Oktober 2013 dengan lokasi daerah Central Business Center meliputi Jalan Sutomo, Jalan Merdeka, Jalan Surabaya, Jalan Bandung, Jalan Thamrin, Jalan Cipto, Jalan Siaosio, Jalan Dr. Wahidin Kota Pematangsiantar.

\section{B. Metodologi Penelitian}


Lokasi penelitian dipilih secara purposive dengan pertimbangan bahwa lokasinya berada pada inti kota, masyarakatnya sebagian besar pedagang, dan memiliki rumah berlantai lebih dari 2 lantai. Penelitian ini menggunakan metode survai dengan menggunakan teknik kombinasi antara observasi dan kuesioner. Penentuan anggota masyarakat yang menjadi responden, dilakukan secara acak dari seluruh lokasi penelitian, yang diharapkan dapat mewakili seluruh unsure lapisan. Jumlah responden ditetapkan sebanyak 100 orang dengan unit penelitian adalah rumah tangga, yang ditarik secara acak (simple random sampling).

Teknik pengumpulan data dilakukan dengan melakukan wawancara secara langsung kepada responden dengan berpedoman pada daftar kuesioner. Untuk mendukung responden mengisi kuesioner, dirancang pertanyaan tertutup.

Data yang terkumpul dari lapangan, akan ditabulasi dalam tabel, yang selanjutnya akan dilakukan scoring data, yaitu jawaban responden terlebih dahulu diberi bobot skor menurut tingkat kualitas jawabannya. Selanjutnya dilakukan klasifikasi responden berdasarkan skor jawaban dengan tabel distribusi frekuensi.

\section{HASIL PENELITIAN}

\section{A. Karakteristik Responden}

Karakteristik responden yang diperoleh meliputi umur, pendidikan, pekerjaan, jenis atap rumah, jumlah lantai rumah dan jumlah anggota keluarga, dan alamat tempat tinggal. Pemaparan karakteristik ini bertujuan untuk mengetahui persepsi dan sikap masyarakat melalui profil sosial ekonominya, disamping memberikan cerminan karakter kepala keluarga yang berada di inti kota Pematangsiantar (central business districk).

Dari tabulasi data, diperoleh umur responden tersebar dari 30 sampai diatas 50 tahun, tersebar dengan persentase umur 30-39 tahun sebesar 30\%, 40-49 tahun sebesar $49 \%$, dan diatas 50 tahun sebesar $21 \%$. Tingkat pendidikan responden cukup baik, dimana dari keseluruhan responden telah menyelesaikan pendidikan menengah, dengan sebaran pendidikan tamat SMP 5\%, SMA sebesar 78\%, Diploma 8\% dan Sarjana 12\%.

Dari hasil penelitian didapat bahwa pekerjaan responden didominasi pada sektor wiraswasta sebesar $62 \%$ dan bidang lainnya $38 \%$. Dari tipe jenis tempat tinggal responden didominasi dengan bangunan permanen dengan jumlah lantai rumah tersebar lantai 1 sebesar $4 \%$, lantai 2 sebesar $13 \%$, lantai 3 sebesar $50 \%$, lantai 4 sebesar $27 \%$ dan lantai 5 sebesar $6 \%$. Jika dilihat jenis atap rumah didapatkan 
bahwa $62 \%$ responden menggunakan lantai beton sebagai atap rumah dan $38 \%$ menggunakan atap dari jenis seng dan lainnya.

Dari gambaran karakteristik responden di atas terlihat bahwa masyarakat yang bermukim di areal central business districk, tergolong masyarakat yang homogen dengan tingkat pendidikan yang memadai dan mendominasi sector ekonomi sebagai pekerjaan.

\section{B. Kesediaan Mendukung Program Kota Hijau}

Kota Pematangsiantar, sebagai kota kedua terbesar di propinsi Sumatera Utara, memiliki masyarakat yang pluralistik baik agama dan etnis telah mencanangkan program kota hijau sejak tahun 2011 yang lalu, hal ini juga dapat dilihat dengan keberhasilan kota Pematangsiantar meraih Piala Adipura tahun 2013 untuk kota sedang. Dari hasil penelitian menunjukkan bahwa sikap responden terhadap kesediaan mendukung program kota hijau menunjukkan sikap yang positif. Secara lengkap seperti ditampilkan pada tabel 1 .

Dari tabel 1, bahwa 9 dari 10 item pertanyaan memberikann nilai antara 50\% sampai dengan $91 \%$, hal ini menunjukkan sikap yang positif dari masyarakat terhadap kesediaan untuk mendukung program kota hijau dan $58 \%$ responden tidak berpendapat jika pemerintah kota membuat atau menetapkan diwilyah kota sebagai daerah pedesterian.

Hal ini dapat diduga karena aktivitas sehari-hari masyarakat dalam kegiatan perekonomian ataupun kultur budaya etnis (tidak terbuka) serta sikap masyarakat kota secara umum.

Secara umum responden memberikan nilai yang tinggi terhadap kesediaan masyarakat mendukung prog-ram kota hijau seperti tertera pada tabel 2.

Dari tabel 2, diatas dapat kita lihat bahwa hasil penjumlahan skor masingmasing responden memberikan nilai yang positif sebesar $48 \%$, bersikap netral sebesar $38 \%$, dan yang negative (rendah) sebesar $14 \%$.

Melihat variasi atas jawaban responden diatas dalam hal kesediaannya, cukup baik namun perlu dibangun motivasi oleh pihak yang berkompeten dalam perencanaan program Pematangsiantar Kota Hijau. Dengan dorongan dan berbagai kegiatan promosi dan penyuluhan, maka upaya menjadikan Pematangsiantar akan terwujud. 
Tabel 1. Sikap Responden terhadap Kesediaan Mendukung Program Kota Hijau

\begin{tabular}{|c|c|c|c|c|c|}
\hline \multirow{2}{*}{ No } & \multirow{2}{*}{ Uraian } & \multicolumn{3}{|c|}{ Jumlah Responden } & \multirow{2}{*}{ Jumlah } \\
\hline & & $1 *$ & $2 *$ & $3 *$ & \\
\hline 1 & $\begin{array}{l}\text { Tanggapan bahwa sebagai masyarakat kota bersedia } \\
\text { mendukung dan mewujudkan program Kota Hijau }\end{array}$ & 83 & 0 & 17 & 100 \\
\hline 2 & $\begin{array}{l}\text { Bersedia ikut serta memelihara dan merawat kawasan- } \\
\text { kawasan ruang terbuka hijau di Kota Pematangsiantar }\end{array}$ & 91 & 0 & 9 & 100 \\
\hline 3 & $\begin{array}{l}\text { Bersedia menambah ruang-ruang terbuka hijau di } \\
\text { lingkungan pemukiman (rumah, atap rumah, pekarangan, } \\
\text { termasuk trotoar) }\end{array}$ & 72 & 4 & 24 & 100 \\
\hline 4 & $\begin{array}{l}\text { Bersedia memulai program kota hijau, dimulai dengan } \\
\text { keluarga dan fasilitas disekitar tempat tinggal }\end{array}$ & 70 & 6 & 24 & 100 \\
\hline 5 & $\begin{array}{l}\text { Sebagai masyarakat kota diperlukan Peraturan Daerah } \\
\text { tentang Kota Hijau }\end{array}$ & 66 & 1 & 33 & 100 \\
\hline 6 & $\begin{array}{l}\text { Sebagai masyarakat kota bersedia diberikan sanksi apabila } \\
\text { melanggar Perda Kota Hijau yang telah dibuat }\end{array}$ & 60 & 11 & 29 & 100 \\
\hline 7 & $\begin{array}{l}\text { Sebagai masyarakat kota, pemerintah kota memberikan } \\
\text { reward/penghargaan/intensif atas dukungan yang } \\
\text { diberikan untuk kota hijau }\end{array}$ & 72 & 3 & 25 & 100 \\
\hline 8 & $\begin{array}{l}\text { Sebagai masyarakat kota, dapat } \\
\text { mendukung/melaksanakan minimal } 4 \text { atribut kota hijau }\end{array}$ & 64 & 5 & 31 & 100 \\
\hline 9 & $\begin{array}{l}\text { Sebagai masyarakat kota mendukung program seperti } \\
\text { "Car Free Day" pada daerah inti kota di Kota } \\
\text { Pematangsiantar }\end{array}$ & 62 & 4 & 34 & 100 \\
\hline 10 & $\begin{array}{l}\text { Sebagai masyarakat kota tidak berkeberatan } \\
\text { dibuat/ditetapkan daerah/wilayah di Kota Pematangsiantar } \\
\text { sebagai daerah pedestrian }\end{array}$ & 39 & 3 & 58 & 100 \\
\hline
\end{tabular}

Keterangan *): 1 = Setuju $2=$ Tidak Setuju $3=$ Tidak Berpendapat

Sumber : Data primer diolah, 2013

Tabel 2. Sebaran Sikap Responden Mendukung Program Kota Hijau

\begin{tabular}{|c|l|c|c|}
\hline \multicolumn{1}{|c|}{ Skor } & \multicolumn{1}{|c|}{ Kategori } & Jumlah Responden & Persentase \\
\hline $26-33$ & Positif & 48 & 48,0 \\
\hline $18-25$ & Netral & 38 & 38,0 \\
\hline $10-17$ & Negatif & 14 & 14,0 \\
\hline \multicolumn{2}{r}{ Jumlah } & 100 & 100 \\
\hline
\end{tabular}




\section{Kesediaan Melaksanakan Prog- ram Kota Hijau}

Daerah pusat kegiatan (DPK) atau central business district (CBD) merupakan pusat kehidupan sosial, ekonomi, budaya dan politik dalam sesuatu kota sehingga pada kawasan ini terdapat bangunan utama untuk kegiatan sosial ekonomi, budaya dan politik. Rute-rute transportasi dari segala penjuru memusat pada kawasan ini se- hingga kawasan ini merupakan kawasan dengan derajat aksesbilitas tertinggi (the most accessible zone within the urban area).

Hasil penelitian menunjukkan bahwa responden menunjukkan sikap yang positif dan netral terhadap kesediaannya melaksanakan program kota hijau. Secara lengkap tertera pada tabel 3.

Tabel 3. Sikap Responden tentang Kesediaan Melaksanakan Program Kota Hijau

\begin{tabular}{|c|c|c|c|c|c|}
\hline \multirow{2}{*}{ No } & \multirow{2}{*}{ Uraian } & \multicolumn{3}{|c|}{ Jumlah Responden } & \multirow{2}{*}{ Jumlah } \\
\hline & & $1 *$ & $2 *$ & $3 *$ & \\
\hline 1 & $\begin{array}{l}\text { Bersedia, daerah didalam/disekitar tempat tinggal } \\
\text { dijadikan areal kawasan hijau (missal atap rumah } \\
\text { dijadikan taman atap (roof garden) atau teras atap } \\
\text { (roof terrace) }\end{array}$ & 63 & 17 & 20 & 100 \\
\hline 2 & $\begin{array}{l}\text { Bersedia, membuat sumur-sumur resapan (contoh } \\
\text { seperti lubang Biopori) di sekitar tempat tinggal }\end{array}$ & 36 & 10 & 54 & 100 \\
\hline 3 & $\begin{array}{l}\text { Bersedia, melakukan pemisahan sampah (sampah } \\
\text { organik dan anorganik) sebelum diangkut petugas }\end{array}$ & 65 & 15 & 20 & 100 \\
\hline 4 & $\begin{array}{l}\text { Bersedia, untuk tidak menggunakan trotoar (bila } \\
\text { selama ini dipergunakan) sebagai tempat aktivitas } \\
\text { dagang dan lainnya }\end{array}$ & 72 & 6 & 22 & 100 \\
\hline 5 & $\begin{array}{l}\text { Bersedia, untuk ikut mendukung program kota hijau } \\
\text { dengan dukungan pembiayaan yang tidak mengikat }\end{array}$ & 36 & 20 & 44 & 100 \\
\hline
\end{tabular}

Keterangan *): $1=$ Setuju $2=$ Tidak Setuju $3=$ Tidak Berpendapat

Sumber : Data primer diolah, 2013

Berdasarkan tabel 3 terlihat, uraian pertanyaan tertinggi adalah responden bersedia, untuk tidak menggunakan trotoar (bila selama ini dipergunakan) sebagai tempat aktivitas dagang dan lainnya (72\%) dan responden bersedia, melakukan pemisahan sampah (sampah organik dan anorganik) sebelum diangkut petugas
(65\%) serta responden bersedia, daerah didalam/disekitar tempat tinggal dijadikan areal kawasan hijau (misal atap rumah dijadikan taman atap (roof garden) atau teras atap (roof terrace) sebesar 63\%.

Melihat data tersebut, kondisi ini menjadi peluang bagi pemerintah kota atas kesediaan masyarakat di inti kota untuk 
menggunakan trotoar sebagai tempat berdagang, yang artinya ada peluang untuk membuat taman-taman disekitar badan jalan. Disamping itu, kesediaan masyarakat untuk melakukan pemisahan sampah sudah menunjukkan suatu atribut kota hijau (green waste) serta persoalan yang selama ini dihadapi masalah lahan untuk membuat taman-taman kota, dari penelitian didapatkan bahwa responden bersedia didaerah sekitar rumah, termasuk atap dan teras rumah dijadikan taman atap (roof garden).

Untuk melihat secara umum sikap responden untuk kesediaannya melaksanakan program kota hijau, seperti tertera pada tabel 4 .

Tabel 4. Sebaran Sikap Responden tentang Kesediaan Melaksanakan Program Kota Hijau

\begin{tabular}{|c|l|c|c|}
\hline \multicolumn{1}{|c|}{ Skor } & \multicolumn{1}{|c|}{ Kategori } & Jumlah Responden & Persentase \\
\hline $26-33$ & Positif & 35 & 35,0 \\
\hline $18-25$ & Netral & 52 & 52,0 \\
\hline $10-17$ & Negatif & 13 & 13,0 \\
\hline \multicolumn{2}{r|}{ Jumlah } & 100 & 100 \\
\hline
\end{tabular}

Berdasarkan hasil penjumlahan

\section{KESIMPULAN DAN SARAN}

skor, $35 \%$ responden memberikan nilai yang tinggi (positif), 52\% memberikan sikap yang netral dan $13 \%$ memberikan sikap yang rendah. Melihat sikap yang ditunjukkan oleh masyarakat, peluang melaksanakan program kota hijau cukup tinggi.

Namun demikian, usaha-usaha penyadaran masih perlu dilakukan mengingat, terdapat $52 \%$ responden bersikap "abu-abu". Upaya penyuluhan dan pendekatan secara intensif, sehingga sikapnya dapat berubah menjadi positif.

\section{A. Kesimpulan}

Berdasarkan hasil penelitian yang telah dilaksanakan dapat ditarik beberapa kesimpulan bahwa sikap responden terhadap kesediaan mendukung program kota hijau menunjukkan sikap yang positif baik untuk kesediaannya melaksanakan program kota hijau.

\section{B. Saran}

Dalam rangka pelaksanaan program kota hijau di Pematangsiantar, dari hasil penelitian disarankan beberapa hal 
perlu dilakukan sosialisasi dan penyuluhan yang lebih intensif. Aparatur pemerintah sebagai pendorong dan pengayom dalam pelaksanaan program kota hijau, serta perlu dilakukan pendekatan terhadap beberapa tokoh masyarakat untuk mengajak masyarakat berpartisipasi aktif dalam pelaksanaan program kota hijau.

\section{PUSTAKA}

Ananda, F. 2010. Sikap Ekosentrik, Antroposentrik dan Apatis terhadap Pencemaran Lingkungan Hidup Biofisik pada Masyarakat Kota Medan. Skripsi Fakultas Psikologi Universitas Sumatera Utara, Medan.

Anonim. 2012. Tata Ruang. Badan Koordinasi Penataan Ruang Nasional. Buletin Edisi Januari Februari 2012. Kementerian Pekerjaan Umum. Jakarta. .2011. Pedoman Green City : Seri Peran Serta Masyarakat dan Pelaku Usaha. Direktorat Budidaya dan Pasca Panen Florikultura. Kementerian Pertanian. Jakarta.

2011. Program Pengembangan Kota Hijau (P2KH) : Panduan Pelaksanaan 2011. Direktorat Jenderal Penataan Ruang. Kementerian Pekerjaan Umum. Jakarta.

---------. 2004. Undang-Undang Republik Indonesia No.32 tahun 2004 Tentang Otonomi dan Kewenangan Daerah.

Azwar, S. 2000. Penyusunan Skala Psikologi. Yogyakarta: Pustaka Pelajar.

Catanese, Anthony James dan James C. Snyder. 1988. Perencanaan Kota,
Terjemahan Ir. Wahyudi. Jakarta: Penerbit Erlangga.

Farhati, F. (1995 ) Sikap Ekosentrik dan Antroposentrik Terhadap Lingkungan. Yogyakarta: Fakultas Psikologi Universitas Gajah Mada.

Yunus, H.A,. 2006. Struktur Tata Ruang Kota.Pustaka Pelajar. Yogyakarta.

Koentjaraningrat. 1987. Metode dan Teknik Penelitian Masyarakat. Jakarta: Gramedia.

Mutiara, K.,E. 2003. Statistik Berbasis Komputer. Penerbit PT. Elex Media Komputindo. Jakarta.

Pusttekkom. 2008. Kualitas Lingkungan Hidup dan Keterbatasan Lingkungan (online), http://www.w3.org/TR/html4/loos e.dtd. diunduh Mei 2013.

Sarlito. WS. 1992. Psikologi Lingkungan. Jakarta: PT. Gramedia Widiasarana Indonesia.

Susilo, Eko Budi. 2003. Menuju Keselarasan Lingkungan Memahami Sikap Teologis Manusia terhadap Pencemaran Lingkungan. Jakarta: Averroes Press.

Soetrisno, Loekman.2004. Menuju Masyarakat Partisipatif. Jakarta: Kanisius.

Usman, Kasim. 1990. Migrasi di Kotakota Besar. Jakarta: PLPIIS.

Wardahana, Wisnu Arya. 2008. Dampak Pencemaran Lingkungan (edisi ke-3). Yogyakarata: Andi Offset. 